\title{
KINEZITERAPIJOS SU VIZUALIU GRIŽTAMUOJU RYŠIU IR BE JO POVEIKIS SERGANČIŲJŲ KAKLINĖS STUBURO DALIES RADIKULOPATIJA SKAUSMO INTENSYVUMUI, MOTYVACIJAI IR FUNKCIJAI
}

\author{
Vydmantė Nekrašaitė, Toma Petkutė, Eglė Lendraitienė \\ Lietuvos sveikatos mokslų universitetas
}

\section{SANTRAUKA}

Tyrimo pagrindimas. Vizualus grį̌tamasis ryšys yra svarbus judesių mokymosi procesui, kuris reabilitacijos srityje naudojamas esant ịvairiems funkciniams sutrikimams, tačiau trūksta tyrimų, analizuojančių kineziterapijos su vizualiu grižtamuoju ryšiu ir be jo poveikị sergančiųų kaklinès stuburo dalies radikulopatija skausmo intensyvumui, funkcinei būklei ir motyvacijai.

Tikslas - ịvertinti sergančiujų kaklinès stuburo dalies radikulopatija skausmo intensyvumo, motyvacijos ir funkcinių rodiklių kaitą taikant kineziterapiją su grịžtamuoju ryšiu ir be jo.

Metodai. Buvo tirta 18 asmenų, kuriems diagnozuota kaklinès stuburo dalies radikulopatija. Jie buvo suskirstyti ị dvi grupes. Pirmai grupei $(\mathrm{n}=9)$ buvo taikoma kineziterapija be vizualaus grịžtamojo ryšio, antrai $(n=9)$ - kineziterpija su vizualiu grį̌tamuoju ryšiu atliekant pratimus prieš veidrodį ir naudojant „Stabilizer“ slègio matavimo prietaisą. Prieš intervenciją ir po jos buvo vertintas skausmo intensyvumas, galvos ir kaklo judesių amplitudès, kaklo lenkiamujų raumenų funkcija bei tiriamųjų motyvacija.

Rezultatai. Abiejose tiriamosiose grupèse sumažejo skausmo intensyvumas $(\mathrm{p}<0,05)$. Po kineziterapijos abiejų grupių tiriamųjų aktyvios galvos ir kaklo judesių amplitudès statistiškai reikšmingai padidejjo $(\mathrm{p}<0,05)$ ir atitiko normas. Giliųjų galvos ir kaklo lenkiamųų raumenų ištvermé abiejose grupèse reikšmingai nepakito $(\mathrm{p}>0,05)$. Po kineziterapijos su vizualiu grįžtamuoju ryšiu padidèjo tiriamujjų vidinès motyvacijos rodikliai $(\mathrm{p}<0,05)$.

Išvados. Taikant kineziterapiją su vizualiu grịžtamuoju ryšiu ir be jo, sumažèjo sergančiujų kaklinès stuburo dalies radikulopatija skausmo intensyvumas ir pagerèjo judesių amplitudè. Kineziterapija su vizualiu grižtamuoju ryšiu buvo veiksmingesnè gerinant motyvaciją.

Raktažodžiai: radikulopatija, kaklo skausmas, kineziterapija, vizualus grịžtamasis ryšys, motyvacija.

\section{IVADAS}

Šių dienų visuomenèje kaklinès stuburo dalies sutrikimai yra viena dažniausių darbingų asmenų problemų. Bendrojoje populiacijoje nuolatiniais ir epizodiniais kaklo skausmais skundžiasi nuo 30 iki 50\% asmenų (Lourenço et al., 2016). Dažniausia skausmo ir nedarbingumo priežastis yra kaklinės stuburo dalies radikulopatija (Rodine, Vernon, 2012). Šis sutrikimas laikomas ketvirtu pagal dažnumą

Copyright (C) 2020 Vydmantė Nekrašaité, Toma Petkute, Egle Lendraitienė. Published by Lithuanian Sports University.

This is an Open Access article distributed under the terms of the Creative Commons Attribution 4.0 International License, which permits unrestricted use, distribution, and reproduction in any medium, provided the original author and source are credited. 
tarp funkcinę negalią sukeliančių ir neigiamai veikiančių gyvenimo kokybę sveikatos sutrikimų, kurių paplitimas kasmet padidejja net 30\% (Cohen, 2015).

Kineziterapijos metu taikomi fiziniai pratimai veiksmingai padeda valdyti radikulopatijos sukeliamus simptomus ir pašalinti jų atsiradimo priežastis. Vizualaus grižtamojo ryšio veiksmingumas jau ịrodytas gydant širdies ir kraujagyslių ligas, neuroraumeninius ir somatomotorinius sutrikimus (Skurvydas, 2011; Giggins et al., 2013). Manoma, kad grižtamojo ryšio gydomasis poveikis glaudžiai susijęs su didejjančiais asmens motyvaciniais rodikliais judesių mokymosi ir valdymo procese (Barandas et al., 2015). Tyrimais (Morales et al., 2018) nustatyta, kad prietaisai su grị̌tamuoju ryšiu veiksmingi gydant juosmeninès stuburo dalies skausmą, o D. Newman'o (2014) tyrimo duomenys rodo teigiamą gydomajị poveikị stiprinant dubens dugno raumenis. Visgi trūksta tyrimų, analizuojančių kineziterapijos su vizualiu grịžtamuoju ryšiu poveikị sergančiụjų kaklinès stuburo dalies radikulopatija funkcinei būklei.

Tyrimo tikslas - ịvertinti sergančiuju kaklinès stuburo dalies radikulopatija skausmo intensyvumo, motyvacijos ir funkcinių rodiklių kaitą taikant kineziterapiją su grị̌̆tamuoju ryšiu ir be jo.

\section{METODAI}

Tiriamieji. Buvo tirta 18 asmenų, kuriems nustatyta kaklinės stuburo dalies radikulopatija. Atrankos kriterijai: 50-60 m. asmenys, sergantys kaklinès stuburo dalies radikulopatija ir kuriems nerekomenduojama bei nebuvo atlikta stuburo chirurginè operacija, jaučiamo skausmo trukmè ilgesnè nei 3 mènesiai, skausmo intensyvumas 3-6 balai ir raštiškas sutikimas dalyvauti tyrime. Tiriamieji atsitiktine tvarka buvo suskirstyti ị dvi tiriamąsias grupes.

Intervencija. Tyrimui atlikti gautas LSMU Bioetikos centro pritarimas (Nr.BEC-KN(B)-120). Pirmai grupei $(\mathrm{n}=9)$ buvo taikomi pratimai be vizualaus grižtamojo ryšio. Pagrindinę kineziterapijos (KT) procedūros dalị sudarẻ kaklo ir pečių lanko raumenų stiprinimo pratimai, pratimai kaklo giliesiems raumenims aktyvuoti ir stiprinti, judesių amplitudei didinti, atpalaidavimo, tempimo pratimai. Antrai grupei $(n=9)$ buvo taikomi pratimai su vizualiu grịžtamuoju ryšiu naudojant pratimus prieš veidrodị ir „Stabilizer“ slègio matavimo prietaisą. Kineziterapijos procedūros vykdavo individualiai, 5 dienas per savaitę, vieną kartą per dieną. Vienos procedūros trukmè 30 min. Intervencijos trukmè - 10 užsièmimų.

\section{Tyrimo metodai}

Skausmo intensyvumas vertintas naudojant Skaitmeninę skausmo analogijos skalę (SAS). Skausmo intensyvumas vertintas 10 balų skalejje: 0 balų - skausmo 
nèra, 1-3 balai - silpnas skausmas, 4-5 balai - vidutinio stiprumo skausmas, 6-8 balai - stiprus skausmas, 9-10 - nepakeliamas skausmas (Breivik et al., 2008).

Galvos ir kaklo judesiu amplitudès vertintos naudojant inklinometrą. Vertinti ir matuoti judesiai: galvos lenkimas, tiesimas, šoninis lenkimas ir sukimas ị abi puses. Judesių amplitudžių normos: a) lenkimas $-60^{\circ}$; b) tiesimas $-75^{\circ}$; c) šoninis lenkimas ị kairę / dešinę puses $-45^{\circ}$; d) sukimas ị kairę / dešinę puses $-80^{\circ}$ (de Koning et al., 2008).

Gilieji galvos ir kaklo lenkiamieji raumenys vertinti naudojant Galvos ir kaklo lenkimo testą slègio matavimo prietaisu „Stabilizer“. Testo metu tiriamojo buvo prašoma atlikti tokị judesị, kaip sakant žodị „taip“ ir spaudžiant ị pagalvėlę išlaikyti $30 \mathrm{mmHg}$ spaudimo pakopą. Tiriamajam negebejjus išlaikyti nurodyto manžetės spaudimo arba jei pakopa buvo išlaikoma mažiau nei $10 \mathrm{~s}$, testas buvo stabdomas ir fiksuojamas rodiklis (de Araujo et al., 2018).

Motyvacija vertinta naudojant Daugiamati sveikatos kontrolès lokuso klausimyną (DSKS). Klausimynas sudarytas iš 18 klausimų, kurie suskirstyti ị 3 sritis, vertinančias pagrindinius sveikatos kontrolès lokuso rodiklius: vidinę kontrolę, atsitiktinumą ir kitų poveikị. Atskirų sričiu taškai nesumuojami. Daugiausia taškų surinkusi sritis parodo, kuriuo kontrolès aspektu asmuo labiausiai tiki. Tyrimo metu buvo vertinamos „Vidinès kontrolès“ ir „Kitų poveikio“ sritys. „Vidinès kontrolès" sritis parodo asmens vidinę motyvaciją, tikèjimą, kad jo sveikata priklauso nuo jo paties elgesio, vidinių veiksnių, požiūrio. „Kitų poveikio“ sritis parodo individo išorinę motyvaciją ir tai, kiek žmogus tiki, kad jo sveikata priklauso ne nuo paties, o nuo kitų asmenų pastangų, jų daromos įtakos (Ross et al., 2015).

Statistinė duomenų analizė atlikta naudojant IBM SPSS Statistics 22.0 programinę įrangą. Rezultatu patikimumui vertinti ir hipotezėms tikrinti buvo naudojama aprašomoji statistika ir neparametriniai kriterijai. Dviem priklausomoms imtims palyginti taikytas Wilcoxon'o kriterijus (Z), nepriklausomoms - Mann'oWhitney'aus kriterijus (U). Skirtumai, kai p $<0,05$, laikyti statistiškai reikšmingais.

\section{TYRIMO REZULTATAI}

Ivertinę skausmo intensyvumą tiek pirmoje grupeje be vizualaus grị̌tamojo ryšio (I) po kineziterapijos $(Z=-2,716 ; p=0,008)$ ir antroje grupejje su vizualiu grịžtamuoju ryšiu (II) po kineziterapijos $(Z=-2,719 ; p=0,010)$ nustatème, kad skausmo intensyvumas statistiškai reikšmingai sumažèjo. Palyginus abieju grupių skausmo intensyvumo pagal SAS rodiklius, nei prieš kineziterapiją ( $U=28$; $p=0,297)$, nei po jos $(U=39,5 ; p=0,931)$ statistiškai reikšmingo skirtumo nenustatyta. 


\section{Lentelè. Galvos ir kaklo judesių amplitudžių rodikliai grupèse prieš kineziterapiją ir po jos}

\begin{tabular}{|c|c|c|c|c|c|c|c|c|}
\hline & \multicolumn{3}{|c|}{$\begin{array}{c}\text { Kineziterapija be } \\
\text { vizualaus grị̌tamojo } \\
\text { ryšio }\end{array}$} & \multicolumn{3}{|c|}{$\begin{array}{l}\text { Kineziterapija su vizualiu } \\
\text { grịžtamuoju ryšiu }\end{array}$} & \multirow{2}{*}{$\begin{array}{c}\begin{array}{c}\text { Lyginant } \\
\text { grupes } \\
\text { pries KT }\end{array} \\
p\end{array}$} & \multirow{2}{*}{$\begin{array}{c}\begin{array}{c}\text { Lyginant } \\
\text { grupes po } \\
\text { KT }\end{array} \\
p\end{array}$} \\
\hline & $\begin{array}{c}\text { Prieš } \\
K T\end{array}$ & $\begin{array}{l}P o \\
K T\end{array}$ & $p$ & $\begin{array}{c}\text { Pries } \\
K T\end{array}$ & Po KT & $p$ & & \\
\hline Lenkimas & 55 & 60 & $0,025 *$ & 55 & 60 & $0,039^{*}$ & 0,75 & 1 \\
\hline Tiesimas & 60 & 65 & $0,014^{*}$ & 65 & 65 & $0,011^{*}$ & 0,605 & 0,931 \\
\hline $\begin{array}{l}\text { Soninis } \\
\text { lenkimas i kairę }\end{array}$ & 40 & 40 & $0,046^{*}$ & 40 & 40 & $0,014^{*}$ & 0,605 & 1 \\
\hline $\begin{array}{l}\text { Šoninis } \\
\text { lenkimas i } \\
\text { dešinę }\end{array}$ & 35 & 40 & $0,008^{*}$ & 35 & 40 & $0,034^{\circ}$ & 0,73 & 1 \\
\hline Sukimas i kairę & 70 & 70 & $0,025^{*}$ & 70 & 75 & $0,008^{*}$ & 0,863 & 0,666 \\
\hline Sukimas ị dešinę & 65 & 70 & $0,023^{*}$ & 70 & 70 & $0,014^{\circ}$ & 0,863 & 0,605 \\
\hline
\end{tabular}

Pastaba. ${ }^{*}-\mathrm{p}<0,05$, statistiškai reikšmingas skirtumas, lyginant rodiklius prieš kineziterapiją ir po jos.

Ivertinus aktyvias galvos ir kaklo judesių amplitudes nustatyta, kad pirmos grupès be vizualaus grịžtamojo ryšio (I) ir antros grupès su vizualiu grižtamuoju ryšiu (II) visos aktyvios galvos ir kaklo judesių amplitudès statistiškai reikšmingai padidejo po taikytos kineziterapijos $(\mathrm{p}<0,05)$. Visgi, palyginus aktyvių galvos ir kaklo judesių amplitudžių rodiklius tarp pirmos ir antros grupès prieš kineziterapiją ir po jos, statistiškai reikšmingo skirtumo nenustatyta $(p>0,05)$. Tyrimo duomenys pateikiami lentelèje.

Ivvertinus ir palyginus $30 \mathrm{mmHg}$ pakopos spaudimo rodiklius pirmoje grupeje be vizualaus grižtamojo ryšio prieš KT ir po jos, statistiškai reikšmingo pokyčio nenustatyta $(p=1)$. Antroje grupèje su vizualiu grižtamuoju ryšiu $30 \mathrm{mmHg}$ pakopos spaudimo rodikliai buvo panašūs, statistiškai reikšmingas pokytis prieš KT ir po jos grupejje taip pat nepastebėtas $(\mathrm{p}=0,25)$. Ivertinus ir palyginus giliųų galvos ir kaklo lenkiamujų raumenų ištvermès testo rodiklius prieš kineziterapiją ir po jos, statistiškai reikšmingų pokyčių ir skirtumų tarp grupių nenustatyta $(\mathrm{p}>0,05)$.

Vertinant tiriamujų vidinès motyvacijos rodiklį, DSKS „Vidinès kontrolès“ rodikliai pirmoje grupejje be vizualaus grižtamojo ryšio prieš kineziterapiją ir po jos, statistiškai reikšmingai nepasikeite $(Z=-1,902 ; p=0,057)$. Lyginant DSKS „Vidinès kontrolès“ rodiklius antroje grupejje su vizualiu grị̌žtamuoju ryšiu prieš kineziterapiją ir po jos, nustatytas statistiškai reikšmingas skirtumas $(Z=-2,670$; 
Kineziterapijos su vizualiu grižtamuoju ryšiu ir be jo poveikis sergančiujų kaklinės stuburo dalies radikulopatija skausmo intensyvumui, motyvacijai ir funkcijai

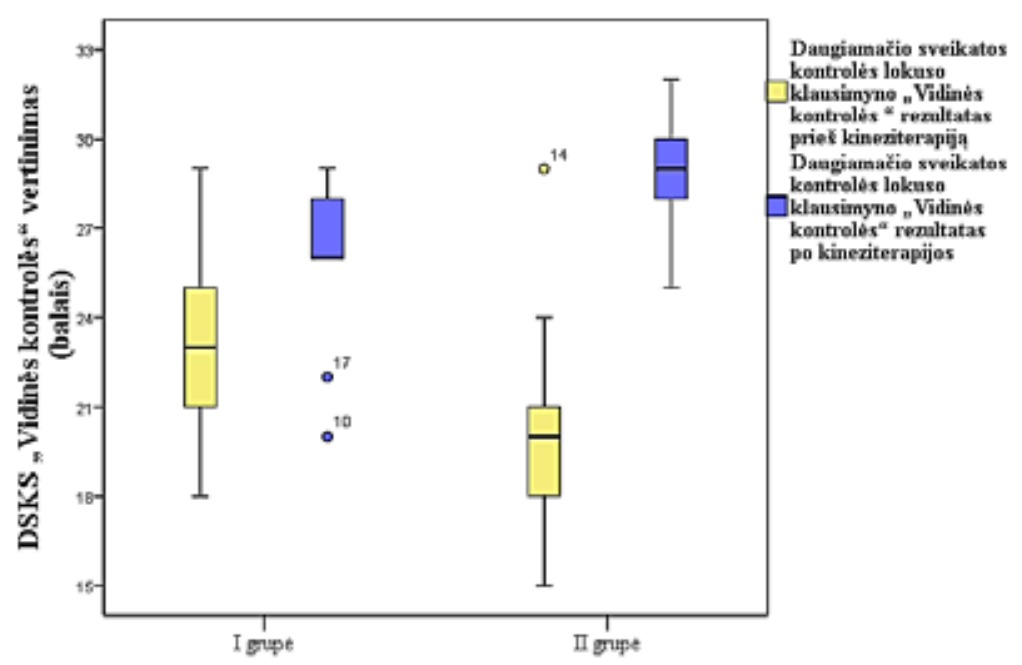

Pastaba. * $-\mathrm{p}<0,05$, statistiškai reikšmingas skirtumas grupejje prieš KT ir po jos; ** $-\mathrm{p}<0,05$, statistiškai reikšmingas skirtumas tarp grupių po KT.

1 pav. DSKS „Vidinès kontrolès“ motyvacijos rodiklio vertinimo rezultatai tarp grupių prieš kineziterapiją ir po jos

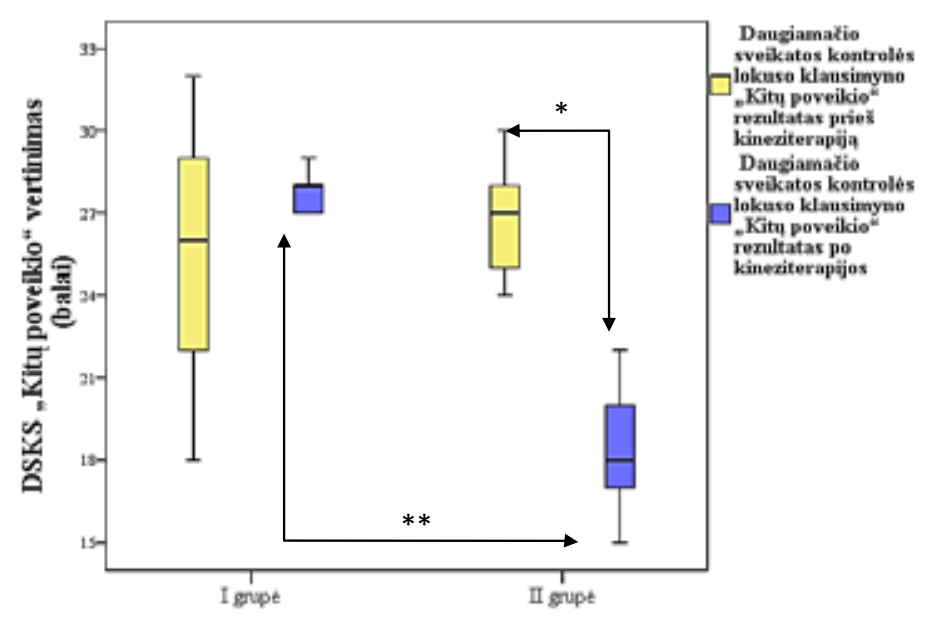

Pastaba. * $-\mathrm{p}<0,05$, statistiškai reikšmingas skirtumas grupèje; ** $-\mathrm{p}<0,05$, statistiškai reikšmingas skirtumas tarp grupių.

2 pav. DSKS „Kitų poveikio“ motyvacijos rodiklio vertinimo rezultatai tarp grupių prieš kineziterapiją ir po jos 
$\mathrm{p}=0,008)$. Palyginus grupių DSKS „Vidinès kontrolès“ rodiklius prieš KT, statistiškai reikšmingas skirtumas nepastebètas $(U=22 ; p=0,113)$, tačiau lyginant grupių rodiklius po KT nustatytas statistiškai reikšmingas skirtumas $(U=16,5 ; p=$ 0,031) (1 pav.)

İvertinus pirmos grupès DSKS „Kitų poveikio“ rodiklius prieš kineziterapiją ir po jos, statistiškai reikšmingo skirtumo nenustatyta $(Z=-0,773 ; p=0,44)$. Antros grupès DSKS „Kitų poveikio“ rodikliai prieš kineziterapiją ir po jos, statistiškai reikšmingai skyrèsi $(Z=-2,670 ; p=0,04)$. Nors palyginus DSKS „Kitų poveikio“ rodiklius tarp pirmos ir antros grupès prieš kineziterapiją statistiškai reikšmingas skirtumas nepastebètas $(U=37 ; p=0,796)$, lyginant rodiklius tarp grupių po kineziterapijos nustatytas statistiškai reikšmingas skirtumas $(U=10 ; p=0,03)(2$ pav. $)$

\section{REZULTATŲ APTARIMAS}

Išanalizavus mūsų tyrimo rezultatus nustatyta, kad taikant kineziterapiją su vizualiu grị̌tamuoju ryšiu ir be jo sumažejo sergančiųjų kaklinès stuburo dalies radikulopatija, skausmo intensyvumas ir pagerejo funkciniai rodikliai. Po kineziterapijos su vizualiu grižtamuoju ryšiu labiau sumažejo išoriniai ir padidejjo vidiniai motyvacijos rodikliai, nei taikant kineziterapiją be vizualaus grižtamojo ryšio.

D. Ribeiro ir kt. (2018) tyrè vienos kineziterapijos procedūros naudojant veidrodị su vizualiu grị̌tamuoju ryšiu ir be jo poveikị asmenų, jaučiančių kaklo skausmą, skausmo intensyvumui ir funkcinei būklei. Po tyrimo statistiškai reikšmingas skirtumas nustatytas kineziterapijos su vizualiu grịžtamuoju ryšiu grupejje, kai buvo vertinamos aktyvios galvos ir kaklo judesių amplitudès. Autoriai pastebi, kad vienos kineziterapijos procedūros su vizualiu grịžtamuoju ryšiu nepakanka siekiant ịvertinti skausmo intensyvumo pokyčius ir daro prielaidą, kad taikant jų daugiau galima sumažinti kaklo skausmo intensyvumą ir pagerinti funkcinę būklę (Ribeiro et al., 2018). Mūsų tyrimo rezultatai iš dalies sutampa su šių autorių teiginiais. Tyrimo metu nustatème aktyvių galvos judesių amplitudžių pagerèjimą ir skausmo intensyvumo sumažèjimą taikant kineziterapiją su vizualiu grižtamuoju ryšiu. Vis dèlto skirtumų tarp grupių, taikant kineziterapiją su vizualiu grižtamuoju ryšiu ir be jo, nustatyti nepavyko.

2013 metais M. Nezamuddin'as ir kt. atliko tyrimą, kurio metu buvo tiriamas kineziterapijos pratimų, skirtų giliųjų kaklo lenkiamųjų raumenų stiprinimui, poveikis mažinant kaklo skausmo intensyvumą, gerinant raumenų funkciją. Šiame tyrime asmenys, jaučiantys kaklo skausmą, buvo suskirstyti ị dvi grupes - pirmą, kuriai buvo taikyti kaklo ir pečių lanko stiprinimo pratimai, ir antrą, kuriai buvo taikomi giliujų galvos ir kaklo raumenų stiprinimo pratimai naudojant slègio matavimo prietaisą su grịžtamuoju ryšiu. Po kineziterapijos antros grupès, kuriai 
buvo taikyta kineziterapija su grį̌tamuoju ryšiu, tiriamujų giliujų kaklo lenkiamųjų raumenų jèga ir ištvermè buvo didesnè, mažesnis skausmo intensyvumas, negu pirmoje grupeje (Nezamuddin et al., 2013). Mūsų tyrimo metu nenustatytas statistiškai reikšmingas skirtumas tarp tiriamų grupių rodiklių. Manome, kad įtakos tokiems rezultatams galèjo turèti iš dalies neilga mūsų tyrimo trukmé.

Z. Mihajlovic'iaus ir kt. (2018) tyrimo duomenys parodè, kad kineziterapija, kurios metu taikomi virtualios realybės žaidimo pratimai su vizualiu grižtamuoju ryšiu, veiksmingai gerina dèmesio koncentravimą ir didina motyvacijos lygị tụ ligonių, kurie jaučia kaklo skausmą (Mihajlovic et al., 2018). Mūsų tyrimo duomenys parodè, kad po kineziterapijos su vizualiu grižtamuoju ryšiu labiau sumažejo išoriniai ir padidejjo vidiniai motyvacijos rodikliai, nei taikant kineziterapiją be vizualaus grị̌tamojo ryšio. Taigi pratimai, atliekami su grịžtamuoju ryšiu, leido tiriamiesiems manyti, kad jų sveikatos būklès pagerējimo rodikliai labiau priklauso nuo jų pačių, o ne nuo kitų asmenų ar aplinkybių daromos ịtakos. Manoma, kad grịžtamojo ryšio gydomasis poveikis glaudžiai susijęs su didejjančiais asmens motyvaciniais rodikliais judesių mokymosi ir valdymo procese (Barandas et al., 2015).

Šio tyrimo rezultatai patvirtina kineziterapijos pratimų, kurių metu aktyvuojami gilieji galvos ir kaklo lenkiamieji raumenys, naudą asmenims, kuriems nustatyta kaklinės stuburo dalies radikulopatija, tačiau hipotezès, kad taikant kineziterapiją kartu su vizualiu grịžtamuoju ryšiu gausime geresnius rezultatus vertindami skausmo intensyvumą ir funkcinę būklę, patvirtinti negalime. Ateityje, siekiant nagrinèti vizualaus grị̌tamojo ryšio poveikị esant šiam sveikatos sutrikimui, rekomenduojame atlikti tyrimą su didesne imtimi ir tiriamiesiems taikyti daugiau kineziterapijos procedūrų.

\section{IŠVADOS}

Taikant kineziterapiją su vizualiu grịžtamuoju ryšiu ir be jo, sumažèjo asmenų, kuriems nustatyta kaklinès stuburo dalies radikulopatija, skausmo intensyvumas ir pagerejo judesių amplitudè. Po kineziterapijos su vizualiu grį̌tamuoju ryšiu labiau sumažèjo sergančiujų kaklinès stuburo dalies radikulopatija išoriniai ir padidejjo vidiniai motyvacijos rodikliai nei tų asmenų, kuriems taikyta kineziterapija be vizualaus grižtamojo ryšio.

Finansavimas: nèra.

Interesų atskleidimas: nèra. 


\title{
LITERATŪRA
}

de Araujo, F. X., Ferreira, G. E., Schell, M. S. et al. (2018). Measurement properties of the craniocervical flexion test: A systematic review protocol. BMJ Open, 8 (2), e 019486.

Barandas, M., Gamboa, H., Fonseca, J. M. (2015). A real time biofeedback system using visual user interface for physical rehabilitation. Procedia Manufacturing, 3, 823-828. http://dx.doi.org/10.1016/j.promfg.2015.07.337

Breivik, H., Borchgrevink, P. C., Allen, S. M. et al. (2008). Assessment of pain. BJA: British Journal of Anaesthesia, 101 (1), 17-24. http://dx.doi.org/10.1016/j.mayocp.2014.09.008

Cohen, S. P. (2015). Epidemiology, diagnosis, and treatment of neck pain. In Mayo Clinic Proceedings (Vol. 90, No. 2, pp. 284-299). Elsevier.

Giggins, O. M., Persson, U. M., Caulfield, B. (2013). Biofeedback in rehabilitation. Journal of Neuroengineering and Rehabilitation, 10 (1), 60.

de Koning, C. H., van den Heuvel, S. P., Staal, J. B., Smits-Engelsman, B. C., Hendriks, E. J. (2008). Clinimetric evaluation of active range of motion measures in patients with non-specific neck pain: A systematic review. European Spine Journal, 17 (7), 905-921.

Lourenço, A. S., Lameiras, C., Silva, A. G. (2016). Neck flexor and extensor muscle endurance in subclinical neck pain: Intrarater reliability, standard error of measurement, minimal detectable change, and comparison with asymptomatic participants in a university student population. Journal of Manipulative and Physiological Therapeutics, 39 (6), 427-433. http://dx.doi.org/10.1016/j.jmpt.2016.05.005

Mihajlovic, Z., Popovic, S., Brkic, K., Cosic, K. (2018). A system for head-neck rehabilitation exercises based on serious gaming and virtual reality. Multimedia Tools and Applications, 77 (15), 19113-19137.

Morales, C. R., Sanz, D. R., Reguera, M. D. L. C. et al. (2018). Proprioceptive Stabilizer ${ }^{\mathrm{TM}}$ training of the abdominal wall muscles in healthy subjects: A quasi-experimental study. Revista da Associação Médica Brasileira, 64 (12), 1134-1138.

Newman, D. K. (2014). Pelvic floor muscle rehabilitation using biofeedback. Urol Nurs, 34 (4), 193-202.

Nezamuddin, M., Anwer, S., Khan, S. A., Equebal, A. (2013). Efficacy of pressure-biofeedback guided deep cervical flexor training on neck pain and muscle performance in visual display terminal operators. Journal of Musculoskeletal Research, 16 (03), 1350011. http://www.worldscientific.com/doi/abs/10.1142/ S0218957713500115

Ribeiro, D., Silva, A. G. (2019). A single session of visual feedback improves range of motion in patients with chronic idiopathic neck pain: A randomized and controlled study. Musculoskeletal Care, 17 (1), 72-78.

Rodine, R. J., Vernon, H. (2012). Cervical radiculopathy: A systematic review on treatment by spinal manipulation and measurement with the Neck Disability Index. The Journal of the Canadian Chiropractic Association, 56 (1), 18 .

Ross, T. P., Ross, L. T., Short, S. D., Cataldo, S. (2015). The multidimensional health locus of control scale: Psychometric properties and form equivalence. Psychological Reports, 116 (3), 889-913.

Skurvydas, A. (2011). Modernioji neuroreabilitacija. Kn. Judesiu valdymas ir proto treniruote. Kaunas: Vitae Litera.

\section{EFFECTS OF PHYSIOTHERAPY WITH AND WITHOUT VISUAL BIOFEEDBACK ON PAIN INTENSITY, MOTIVATION AND FUNCTION IN PERSONS WITH CERVICAL RADICULOPATHY}

\author{
Vydmantė Nekrašaitė, Toma Petkutė, Eglė Lendraitienė \\ Lithuanian University of Health Sciences
}

ABSTRACT

Background. Visual biofeedback has been used in rehabilitation after various functional impairments and plays an important role in improving motor control. 
However, there is a lack of research analysing the effect of exercise, only physical therapy intervention versus visual biofeedback based exercise training for individuals with cervical radiculopathy in reducing pain intensity and increasing functional status and motivation.

Aim. The aim was to evaluate the effect of physiotherapy with and without biofeedback on pain intensity, motivation and function in individuals with cervical radiculopathy.

Methods. The study included 18 participants with cervical radiculopathy, who were randomly assigned into two groups. The first group $(n=9)$ received basic physiotherapy intervention (with no visual biofeedback) and the second group $(\mathrm{n}=9)$ - physiotherapy intervention with visual feedback using mirror and pressure biofeedback unit. Both groups received 10 physiotherapy interventions. Before and after intervention pain intensity, active ranges of motion of the head and cervical spine were assessed as well as the function of the deep cervical flexor muscles and motivation of patients.

Results. The neck pain intensity decreased in both groups after intervention $(p<0.05)$. After both interventions active ranges of motion of cervical spine significantly improved $(p<0.05)$. There was no significant change in deep cervical flexor muscle function $(\mathrm{p}<0.05)$. The internal rate of motivation was increased in individuals with cervical radiculopathy when using visual biofeedback exercise $(\mathrm{p}<0.05)$.

Conclusions. Physiotherapy with and without visual feedback reduced pain intensity and range of motion in individuals with cervical radiculopathy. Physiotherapy with visual feedback was more effective in improving motivation.

Keywords: radiculopathy, neck pain, physiotherapy, visual feedback, motivation.

Gautas 20201011

Priimtas 20201210 